\title{
Caecal fermentation and energy accumulation in the rat fed on indigestible oligosaccharides
}

\author{
Ei Sakaguchi*, Chie Sakoda and Yoko Toramaru \\ Laboratory of Animal Nutrition, Faculty of Agriculture, Okayama University, Tsushima-naka 1-1-1, Okayama 700, Japan
}

(Received 2 April 1998 - Revised 9 June 1998 - Accepted 11 June 1998)

\begin{abstract}
The energetic contribution from, and effects on the gastrointestinal tract of, indigestible oligosaccharides in growing rats were compared with those of sucrose (S). S and two types of oligosaccharides, fructo-oligosaccharide (Fru) and $6^{\prime}$-galacto-oligosaccharide (Gal) were added to a basal diet at a level of $100 \mathrm{~g} / \mathrm{kg}$. The basal diet was given either ad libitum (group B) or at a level approximately $90 \%$ of the ad libitum intakes of the Fru and Gal groups (group BR). During a $50 \mathrm{~d}$ feeding period, feed intake, digestibilities of nutrients, and digesta retention times using liquid (Co-EDTA) and particulate (Cr-cell-wall constituents) markers were measured. The carcass and the contents of the stomach and caecum were sampled on the last day of the experimental period. There was no significant difference in feed intake between groups other than BR. Addition of Fru and Gal to the basal diet resulted in increased crude ash digestibility and decreased crude protein and fat digestibilities. Mean retention times of digesta markers were increased by addition of Fru and Gal to the diet, and this was associated with enlargement of the caecum. Concentrations and amounts of total organic acids in the caecum were higher in groups Fru and Gal than the other groups. The amount of energy accumulated in the carcass of rats in the Gal group was significantly $(P<0.05)$ lower than that of rats fed on $\mathrm{S}$ but not Fru. Contributions to energy accumulation tended to be different between Fru and Gal; these were associated with differences in composition of caecal organic acids and of fatty acids in body fat.
\end{abstract}

Oligosaccharides: Caecum: Fermentation: Energy contribution

Unabsorbable carbohydrates (non-starch oligo- and polysaccharides) escape digestion in the rat small intestine and reach the large intestine, where they are fermented mainly to short-chain fatty acids (SCFA) and lactic acid. SCFA are readily absorbed (Hagen \& Robinson, 1953) and utilized as a source of energy in epithelial cells of the large intestine (Henning \& Hird, 1972; Roediger, 1980) and in the liver (Demigné et al. 1986; Schumann et al. 1991).

Fructo-oligosaccharides and galacto-oligosaccharides are classified as indigestible oligosaccharides because of their resistance to digestion in the small intestine. These oligosaccharides are metabolized mainly to SCFA by intestinal micro-organisms, and the SCFA are absorbed and further utilized in body tissues (Hosoya et al. 1988; Matsumoto et al. 1993).

In the present study we estimated the contribution to energy accumulation of these indigestible oligosaccharides, which enter the intermediary metabolism of the animal via microbial fermentation in the large intestine. The energy supplied by each oligosaccharide can be expected to vary, depending on its fermentability and the metabolic pathways involved in the intermediary metabolism of each organic acid absorbed. Therefore, the estimation of the energy contribution of indigestible oligosaccharides must be based on biological assay.

The purpose of the present study was to determine the relative energy contribution of indigestible but fermentable oligosaccharides by measuring energy accumulation in rats fed on different oligosaccharides. Energy contributions were compared with that of the easily digestible disaccharide sucrose, which is commonly used as a sweetening agent.

\section{Materials and methods \\ Animals and feeding}

Male growing Wistar rats with an initial mean body mass of $70 \mathrm{~g}$ were used. The rats were randomly divided into five groups of seven individuals. They were kept individually in wire-mesh cages in an air-conditioned room maintained at $23 \pm 1^{\circ}$ with a constant light-dark cycle (14 h light: $10 \mathrm{~h}$ dark). At the beginning of the experiment, two rats, which were the heaviest and the lightest among the rats used for the feeding trial, were killed by exsanguination under 
oxide) $(1: 1, \mathrm{v} / \mathrm{v})$. The mixture was allowed to stand for $1 \mathrm{~h}$, then methanol-ethanol-n-hexane (1:1:1, by vol.) was added, to a final volume of $10 \mathrm{ml}$. This solution was used for analysis of fatty acids. Acetonitrile was used as the eluent in the HPLC, at a flow rate of $1.5 \mathrm{ml} / \mathrm{min}$ at ambient temperature.

The concentration of organic acids in caecal contents was determined by the method described by Kikuchi \& Yajima (1992) with HPLC (ICA-3000; Toa Electronics Co. Ltd., Tokyo, Japan).

\section{Calculations}

Energy accumulation in the body was estimated by subtracting energy content in the body at the beginning of the experiment from the energy content in the body at the end of the experiment. The energy content at the beginning of the experiment was calculated by multiplication of mean energy concentration ( $\mathrm{kJ} / \mathrm{g}$ body weight) of two rats and body weight $(\mathrm{g})$ at the beginning of the experiment.

Rats can be considered to have two mixing pools of digesta, stomach and caecum. However, concentrations of $\mathrm{Cr}$ and $\mathrm{Co}$ reached a peak value rapidly after their first appearance in the faeces, then declined, following a straight line on a semilog scale, suggesting that single compartment analysis could be used to calculate mean retention times of digesta markers. Therefore, single exponential regression equations were fitted statistically to time-course declines of faecal concentrations of $\mathrm{Cr}$ and $\mathrm{Co}$. The turnover time of each marker was estimated from the decline in faecal concentration of marker by the function (Brandt \& Thacker, 1958):

$$
\mathrm{Y}=\mathrm{Y}_{0} \times \mathrm{e}^{-k \mathrm{t}}
$$

where $\mathrm{Y}$ is the concentration of $\mathrm{Cr}$ or $\mathrm{Co}$ in faeces at time $\mathrm{t}$, $\mathrm{Y}_{0}$ is the constant depending on the level of $\mathrm{Cr}$ and $\mathrm{Co}$ given, $k$ is the rate constant and $\mathrm{t}$ is the time interval after feeding of the markers (h). Turnover time was calculated as the reciprocal of the rate constant $(k)$ of the exponential curve fitted to the time-course excretion values of the markers after faecal marker concentration reached a maximum. Total mean retention time in the gastrointestinal tract was calculated as the sum of the reciprocal of $k$ and transit time, the time of first appearance of the marker after a dose. Mean retention time of digesta was calculated also by the total collection method (Coombe \& Kay, 1965).

The contribution of each oligosaccharide to energy accumulation in the body was estimated using the following equations:

$$
\begin{gathered}
\mathrm{EA}_{\mathrm{S}, \mathrm{Fru}, \mathrm{Gal}}=\mathrm{ETA}_{\mathrm{S}, \mathrm{Fru}, \mathrm{Gal}}-\mathrm{ARE}_{\mathrm{BR}} \times \mathrm{I}_{\mathrm{Basal}}, \\
\mathrm{ARE}_{\mathrm{S}, \mathrm{Fru}, \mathrm{Gal}}=\left(\mathrm{EA}_{\mathrm{S}, \mathrm{Fru}, \mathrm{Gal}} / \mathrm{I}_{\mathrm{S}, \mathrm{Fru}, \mathrm{Gal}}\right) \times 100,
\end{gathered}
$$

where $\mathrm{EA}_{\mathrm{S}, \mathrm{Fru}, \mathrm{Gal}}$ is the energy accumulation from $\mathrm{S}$, Fru or

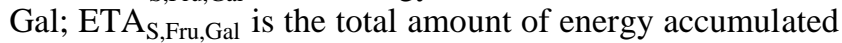
in the rat carcass of each group; $\mathrm{ARE}_{\mathrm{BR}}$ is the energy accumulation rate ((amount of energy accumulated)/(total food intake)) in group BR rats; $\mathrm{I}_{\mathrm{Basal}}$ is the intake of the basal diet ((total feed intake) $\times 100 / 110)$ of each group fed with a sugar or oligosaccharide; $\mathrm{ARE}_{\mathrm{S}, \mathrm{Fru}, \mathrm{Gal}}$ is the energy accumulation rate of each sugar or oligosaccharide and $\mathrm{I}_{\mathrm{S}, \mathrm{Fru}, \mathrm{Gal}}$ is the intake of each sugar or oligosaccharide ((total feed intake) $\times 10 / 100)$.

\section{Statistical analysis}

The data were analysed as a single factorial design and tested for statistical difference by Duncan's multiple range test (Duncan, 1955).

\section{Results}

\section{Food intake and weight gain (Table 2)}

Mean values of actual food intake (offered minus refusals and spillage) during the $50 \mathrm{~d}$ experimental period were almost the same in the groups of rats which were fed $a d$ libitum (groups B, S, Fru, Gal). The rats which were given restricted amounts of the basal diet (group BR) consumed $89 \%$ of that consumed by group B.

Weight gains are listed not only as gross but also as net

\begin{tabular}{|c|c|c|c|c|c|c|}
\hline & \multicolumn{5}{|c|}{ Diet } & SEM \\
\hline Feed intake (g/50 d) & $1063 \cdot 4^{a}$ & $944 \cdot 1^{b}$ & $1051 \cdot 8^{a}$ & $1030 \cdot 6^{\mathrm{a}}$ & $1015 \cdot 8^{a}$ & $25 \cdot 5$ \\
\hline $\begin{array}{l}\text { Weight gain }(\mathrm{g} / 50 \mathrm{~d}) \\
\text { Gross† } \\
\text { Net‡ }\end{array}$ & $\begin{array}{l}368 \cdot 6 \\
364 \cdot 3^{a}\end{array}$ & $\begin{array}{l}327 \cdot 5 \\
323 \cdot 0^{b}\end{array}$ & $\begin{array}{l}372 \cdot 2 \\
368 \cdot 1^{a}\end{array}$ & $\begin{array}{l}354 \cdot 7 \\
344 \cdot 2^{\mathrm{a}}\end{array}$ & $\begin{array}{l}346 \cdot 4 \\
337 \cdot 7^{\mathrm{ab}}\end{array}$ & $\begin{array}{l}15 \cdot 2 \\
15 \cdot 1\end{array}$ \\
\hline $\begin{array}{l}\text { Feed efficiency§ (\%) } \\
\text { Gross† } \\
\text { Netł }\end{array}$ & $\begin{array}{l}0.346 \\
0.342\end{array}$ & $\begin{array}{l}0.347 \\
0.342\end{array}$ & $\begin{array}{l}0.354 \\
0.350\end{array}$ & $\begin{array}{l}0.344 \\
0.334\end{array}$ & $\begin{array}{l}0.341 \\
0.332\end{array}$ & $\begin{array}{l}0.010 \\
0 \cdot 010\end{array}$ \\
\hline
\end{tabular}

Table 2. Feed intake, weight gain and feed efficiency in rats fed on diets containing different oligosaccharides*

(Mean values with their pooled standard errors) 
Table 3. Apparent digestibilities $(\mathrm{g} / \mathrm{g})$, in rats, of diets containing different oligosaccharides* (Mean values with their pooled standard errors)

\begin{tabular}{|c|c|c|c|c|c|c|}
\hline & \multicolumn{5}{|c|}{ Diet } & \multirow[b]{2}{*}{ SEM } \\
\hline & $\mathrm{B}(n 7)$ & $\mathrm{BR}(n 7)$ & $S(n 6)$ & Fru $(n 7)$ & $\mathrm{Gal}(n 7)$ & \\
\hline $\mathrm{DM}$ & $0 \cdot 848^{a}$ & $0.855^{\mathrm{b}}$ & $0.865^{c}$ & $0.852^{a}$ & $0.851^{a}$ & 0.002 \\
\hline Organic matter & $0.854^{\mathrm{a}}$ & $0.861^{b}$ & $0.871^{\mathrm{c}}$ & $0.856^{a}$ & $0.855^{\mathrm{a}}$ & 0.002 \\
\hline Crude protein & $0.940^{\mathrm{a}}$ & $0.950^{\mathrm{b}}$ & $0.944^{\mathrm{a}}$ & $0.909^{c}$ & $0.915^{c}$ & 0.002 \\
\hline Crude fat & $0.973^{a b}$ & $0.978^{\mathrm{a}}$ & $0.968^{\mathrm{bc}}$ & $0.960^{d}$ & $0.966^{c d}$ & 0.003 \\
\hline ADF & 0.040 & 0.045 & 0.046 & 0.042 & 0.032 & 0.016 \\
\hline NDF & $0 \cdot 110^{\mathrm{a}}$ & $0 \cdot 150^{\mathrm{b}}$ & $0 \cdot 132^{\mathrm{ab}}$ & $0 \cdot 113^{a}$ & $0 \cdot 127^{\mathrm{ab}}$ & 0.014 \\
\hline Crude ash & $0.725^{\mathrm{a}}$ & $0.743^{\mathrm{ab}}$ & $0.737^{\mathrm{ab}}$ & $0.751^{\mathrm{b}}$ & $0.756^{\mathrm{b}}$ & 0.009 \\
\hline Gross energy & $0.873^{\mathrm{a}}$ & $0.880^{\mathrm{b}}$ & $0.886^{c}$ & $0.869^{a}$ & $0.872^{\mathrm{a}}$ & 0.002 \\
\hline
\end{tabular}

$\mathrm{B}$, basal diet offered ad libitum; BR, basal diet restricted to approximately $90 \%$ of the intake of group B; $\mathrm{S}$, diet containing $100 \mathrm{~g}$ sucrose/kg; Fru, diet containing $100 \mathrm{~g}$ fructo-oligosaccharide/kg; Gal, diet containing $100 \mathrm{~g}$ galacto-oligosaccharide/kg; ADF, acid-detergent fibre (Van Soest, 1963); NDF, neutral-detergent fibre (Van Soest \& Wine, 1967).

a,b,c,d Mean values within a row not sharing a common superscript letter were significantly different, $P<0.05$

${ }^{*}$ For details of diets and procedures, see Table 1 and pp. 469-471.

values because of the variance of the weight of caecal contents between groups. The weights $(\mathrm{g})$ of caecal tissue and caecal contents were $0 \cdot 6$ and $3 \cdot 1$ for group B, $0 \cdot 5$ and $3 \cdot 2$ for group BR, $0 \cdot 6$ and $3 \cdot 0$ for group $S, 1 \cdot 3$ and $8 \cdot 2$ for group Fru and 1.2 and $7 \cdot 0$ for group Gal. Both tissue and content weights of groups Fru and Gal were significantly $(P<0 \cdot 05)$ higher than those of the other groups.

The net weight gain of group BR was significantly $(P<0.05)$ smaller than those of the other groups. The rats of groups Fru and Gal gained slightly less weight than those of groups B and S, but the difference was not statistically significant.

\section{Digestibility (Table 3)}

Apparent digestibilities of DM, organic matter and gross energy were higher in group $S$ than in the other four groups, and higher in group BR than in group B. Digestibility of crude protein was lower in groups Fru and Gal than the other three groups, and was also higher in group BR than in group B. The digestibility of crude ash was higher in groups Fru and Gal than in group B.

\section{Digesta retention time (Table 4)}

Mean retention times of digesta markers were estimated by both compartmental analysis and total collection. Addition of fructo- and galacto-oligosaccharide (groups Fru and Gal) resulted in longer retention times of digesta markers. However, there was no significant difference in transit time between any of the groups. The fluid digesta marker passed through the intestine faster than the particle digesta marker.

Table 4. Transit time (TT, h) and mean retention time (MRT, h) of digesta markers $(\mathrm{Cr}$ and $\mathrm{Co})$ in rats fed on diets containing different oligosaccharides†

(Mean values with their pooled standard errors)

\begin{tabular}{|c|c|c|c|c|c|c|c|}
\hline & & \multicolumn{5}{|c|}{ Diet } & \multirow[b]{2}{*}{ SEM } \\
\hline & & $\mathrm{B}(n 7)$ & $\mathrm{BR}(n 7)$ & $S(n 6)$ & Fru $(n 7)$ & Gal $(n 7)$ & \\
\hline \multirow[t]{4}{*}{$\mathrm{Cr}$} & $1 / k \ddagger$ & $11 \cdot 4^{a}$ & $14 \cdot 2^{\mathrm{ab}}$ & $13 \cdot 3^{\mathrm{ab}}$ & $22 \cdot 1^{c}$ & $18 \cdot 3^{\mathrm{bc}}$ & $2 \cdot 3$ \\
\hline & TT§ & $10 \cdot 3^{*}$ & $9 \cdot 3^{*}$ & $10 \cdot 9^{*}$ & $12 \cdot 7^{*}$ & $11 \cdot 3^{*}$ & $1 \cdot 4$ \\
\hline & MRT\| & $21 \cdot 7^{a}$ & $23 \cdot 5^{\mathrm{a}}$ & $24 \cdot 2 a^{*}$ & $34 \cdot 8^{b}$ & $29 \cdot 6^{\mathrm{ab}}$ & $2 \cdot 6$ \\
\hline & $\sum \mathrm{x}_{i} \mathrm{t}_{i} / \sum \mathrm{x}_{i} \boldsymbol{\Phi}$ & $21 \cdot 9^{\mathrm{ab}}$ & $24 \cdot 1^{\text {ab }}$ & $21 \cdot 1^{a}$ & $26 \cdot 9^{b}$ & $26 \cdot 0^{\mathrm{ab}}$ & $2 \cdot 4$ \\
\hline \multirow[t]{4}{*}{ Co } & 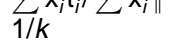 & $12 \cdot 4^{\mathrm{a}}$ & $15 \cdot 4^{\mathrm{a}}$ & $13 \cdot 6^{a}$ & $25 \cdot 3^{\mathrm{b}}$ & $21 \cdot 7^{\mathrm{b}}$ & $2 \cdot 2$ \\
\hline & TT & $5 \cdot 0$ & 3.6 & $4 \cdot 4$ & $4 \cdot 4$ & $5 \cdot 6$ & $1 \cdot 2$ \\
\hline & MRT & $17 \cdot 4^{\mathrm{a}}$ & $19 \cdot 0^{\mathrm{ab}}$ & $18 \cdot 0^{\mathrm{a}}$ & $29 \cdot 7^{b}$ & $27 \cdot 3^{\mathrm{b}}$ & 2.5 \\
\hline & $\sum \mathrm{x}_{i} \mathrm{t}_{i} / \sum \mathrm{x}_{i}$ & $22 \cdot 6^{a}$ & $24 \cdot 1^{a b}$ & $22 \cdot 0^{a}$ & $28 \cdot 6^{b}$ & $27 \cdot 1^{\mathrm{ab}}$ & $2 \cdot 4$ \\
\hline
\end{tabular}

B, basal diet offered ad libitum; BR, basal diet restricted to approximately $90 \%$ of the intake of group B; S, diet containing $100 \mathrm{~g}$ sucrose/kg diet; Fru, diet containing $100 \mathrm{~g}$ fructo-oligosaccharide/kg; Gal, diet containing $100 \mathrm{~g}$ galacto-oligosaccharide/kg; Cr, particle marker (Cr-mordanted cell-wall constituents); Co, liquid marker, Co-EDTA.

a,b,c Mean values within a row not sharing a common superscript letter were significantly different, $P<0.05$.

Mean values were significantly different from those for Co, ${ }^{*} P<0.05$.

†For details of diets and procedures, see Table 1 and pp. 469-471.

$\ddagger$ Turnover time $(h)$ of the marker in the whole digestive tract $(k$ is the rate constant which is the dilution rate (per $h$ ) of the marker in the digestive tract).

$\S$ Time interval between feeding and first appearance of the marker in the faeces.

$\|$ Sum of $1 / k$ and TT.

q MRT calculated using the method described by Coombe \& Kay (1965), where $x_{i}$ is the amount of marker excreted in the $i_{-}$-th collection period and $t_{i}$ is the collection time (h) after marker dose. 
Table 5. Body composition and energy accumulation $(\mathrm{kJ})$ in rats fed on diets containing different oligosaccharides* (Mean values with their pooled standard errors)

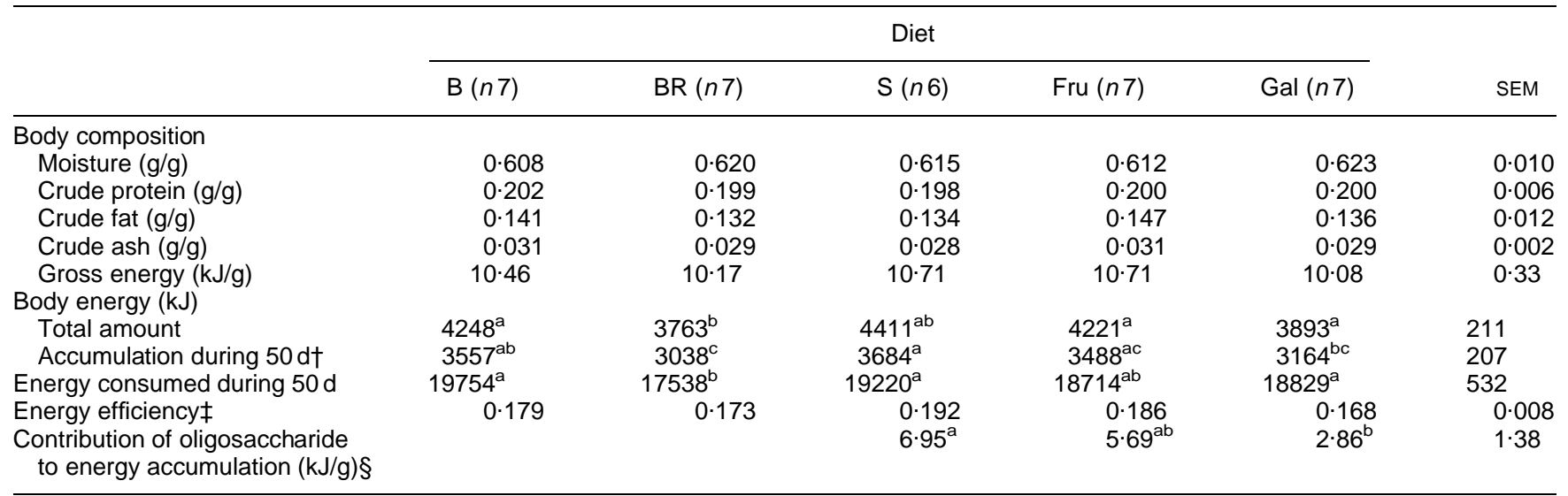

B, basal diet offered ad libitum; BR, basal diet restricted to approximately $90 \%$ of the intake of group B; S, diet containing $100 \mathrm{~g}$ sucrose $/ \mathrm{kg}$; Fru, diet containing $100 \mathrm{~g}$ fructo-oligosaccharide/kg; Gal, diet containing $100 \mathrm{~g}$ galacto-oligosaccharide/kg.

a,b,c Mean values within a row not sharing a common superscript letter were significantly different, $P<0.05$.

${ }^{*}$ For details of diets and procedures, see Table 1 and pp. 469-471.

† Difference between energy content of the body at the beginning of the experiment and energy content of the body at the end of the experiment. $\ddagger$ Energy accumulated: energy consumed.

$\S$ Energy accumulation from oligosaccharides : oligosaccharides consumed. For details of calculation, see p. 471

\section{Body composition and energy accumulation (Table 5)}

Concentrations of moisture, crude protein, crude fat, crude ash and gross energy in the body were similar for all groups.

Rats in group BR accumulated less energy in the carcass than group B rats due to their lower energy consumption. The amount of energy accumulated in group $\mathrm{S}$ was significantly $(P<0.05)$ higher than that of group Gal, but not significantly higher than that of group Fru.

The estimated contributions of the sugar or oligosaccharide to energy accumulation were similar for groups $\mathrm{S}$ and Fru, and both were higher than group Gal.

\section{Caecal organic acids (Table 6)}

Total organic acid concentration was higher in groups Fru and Gal than in the other three groups. There were also much higher amounts of organic acids in the caecum because of both the higher concentration and the larger caecal volume of rats from groups Fru and Gal compared with the other groups. Succinic acid and lactic acid were produced much more in groups Fru and Gal than in the other groups. It is noticeable that the concentrations of each organic acid were different for groups Fru and Gal; acetic acid was much higher in group Gal, but succinic and

Table 6. Concentration ( $\mu \mathrm{mol} / \mathrm{g}$ contents) and total amount $(\mu \mathrm{mol})$ of organic acids in the caecal digesta of rats fed on diets containing different oligosaccharides*

(Mean values with their pooled standard errors)

\begin{tabular}{|c|c|c|c|c|c|c|}
\hline & \multicolumn{5}{|c|}{ Diet } & \multirow[b]{2}{*}{ SEM } \\
\hline & $\mathrm{B}(n 7)$ & $\mathrm{BR}(n 7)$ & $S(n 6)$ & Fru $(n 7)$ & Gal $(n 7)$ & \\
\hline \multicolumn{7}{|l|}{ Concentration } \\
\hline Succinic acid & $0 \cdot 8^{\mathrm{a}}$ & $0 \cdot 8^{\mathrm{a}}$ & $0.9^{a}$ & $13 \cdot 1^{\mathrm{b}}$ & $4 \cdot 3^{c}$ & $1 \cdot 0$ \\
\hline Lactic acid & $4 \cdot 5^{\mathrm{a}}$ & $4 \cdot 6^{\mathrm{a}}$ & $6 \cdot 9^{a b}$ & $13 \cdot 7^{\mathrm{bc}}$ & $20 \cdot 1^{\mathrm{c}}$ & $4 \cdot 0$ \\
\hline Formic acid & $0 \cdot 8^{a}$ & $0 \cdot 7^{\mathrm{a}}$ & $0.9^{a}$ & $2 \cdot 0^{\mathrm{ab}}$ & $5 \cdot 0^{\mathrm{b}}$ & 0.9 \\
\hline Acetic acid & $41 \cdot 0^{\mathrm{ab}}$ & $35 \cdot 3^{\mathrm{b}}$ & $46 \cdot 9^{a}$ & $33.9^{\mathrm{b}}$ & $79 \cdot 2^{c}$ & 4.9 \\
\hline Propionic acid & $12 \cdot 9^{\mathrm{ac}}$ & $11 \cdot 2^{\mathrm{ac}}$ & $14 \cdot 6^{\mathrm{a}}$ & $19 \cdot 6^{\mathrm{b}}$ & $9 \cdot 2^{\mathrm{C}}$ & $2 \cdot 2$ \\
\hline Isobutyric acid & $1 \cdot 0^{\mathrm{a}}$ & $0.9^{a}$ & $1 \cdot 2^{a}$ & $0 \cdot 4^{\mathrm{b}}$ & $0 \cdot 1^{\mathrm{b}}$ & 0.2 \\
\hline Butyric acid & $7 \cdot 9^{\mathrm{a}}$ & $7 \cdot 4^{\mathrm{a}}$ & $8 \cdot 5^{\mathrm{a}}$ & $40 \cdot 0^{\mathrm{b}}$ & $19 \cdot 2^{c}$ & $2 \cdot 7$ \\
\hline Isovaleric acid & $1 \cdot 5^{\mathrm{a}}$ & $1 \cdot 3^{\mathrm{a}}$ & $1 \cdot 5^{\mathrm{a}}$ & $0 \cdot 7^{\mathrm{b}}$ & $0 \cdot 4^{\mathrm{b}}$ & 0.2 \\
\hline Valeric acid & $1 \cdot 2$ & 0.9 & $1 \cdot 2$ & 0.6 & trace & 0.3 \\
\hline Total acids & $71 \cdot 5^{\mathrm{ab}}$ & $63 \cdot 1^{\mathrm{a}}$ & $82 \cdot 5^{b}$ & $123 \cdot 9^{\mathrm{c}}$ & $137 \cdot 4^{c}$ & $9 \cdot 9$ \\
\hline Acetic acid : propionic acid & $3 \cdot 2^{\mathrm{a}}$ & $3 \cdot 2^{a}$ & $3 \cdot 2^{\mathrm{a}}$ & $2 \cdot 0^{\mathrm{a}}$ & $8 \cdot 8^{\mathrm{b}}$ & 0.6 \\
\hline \multicolumn{7}{|l|}{ Total amount } \\
\hline Total acids & $221 \cdot 9^{a}$ & $195 \cdot 4^{\mathrm{a}}$ & $241 \cdot 2^{\mathrm{a}}$ & $1005 \cdot 9^{b}$ & $969 \cdot 5^{\mathrm{b}}$ & $81 \cdot 8$ \\
\hline Total fatty acids & $205 \cdot 6^{a}$ & $179 \cdot 1^{\mathrm{a}}$ & $218 \cdot 1^{a}$ & $788 \cdot 3^{b}$ & $803 \cdot 9^{b}$ & 68.6 \\
\hline
\end{tabular}

B, basal diet offered ad libitum; BR, basal diet restricted to approximately $90 \%$ of the intake of group B; S, diet containing $100 \mathrm{~g}$ sucrose/kg; Fru, diet containing $100 \mathrm{~g}$ fructo-oligosaccharide/kg; Gal, diet containing $100 \mathrm{~g}$ galacto-oligosaccharide/kg.

a,b,c Mean values within a row not sharing a common superscript letter were significantly different, $P<0.05$.

* For details of diets and procedures, see Table 1 and pp. 469-471. 
Table 7. Composition ( $\mathrm{mg} / \mathrm{g}$ total fatty acid) of the body fat of rats fed on diets containing different oligosaccharides* (Mean values with their pooled standard errors)

\begin{tabular}{|c|c|c|c|c|c|c|}
\hline & \multicolumn{5}{|c|}{ Diet } & SEM \\
\hline \multicolumn{7}{|l|}{ Concentration } \\
\hline Linoleic acid & $174 \cdot 2^{\mathrm{a}}$ & $110 \cdot 3^{b}$ & $114 \cdot 9^{b}$ & $82 \cdot 7^{\mathrm{b}}$ & $83 \cdot 2^{b}$ & $15 \cdot 5$ \\
\hline Oleic acid & $255 \cdot 9^{a}$ & $215 \cdot 1^{\mathrm{b}}$ & $203 \cdot 4^{\mathrm{b}}$ & $146 \cdot 1^{\mathrm{c}}$ & $195 \cdot 7^{\mathrm{b}}$ & $16 \cdot 5$ \\
\hline Myristic acid & $204 \cdot 7^{\mathrm{a}}$ & $326 \cdot 6^{\mathrm{b}}$ & $314 \cdot 9^{b}$ & $385 \cdot 5^{\mathrm{b}}$ & $367 \cdot 9^{b}$ & $30 \cdot 9$ \\
\hline
\end{tabular}

$\mathrm{B}$, basal diet offered ad libitum; BR, basal diet restricted to approximately $90 \%$ of the intake of group B; S, diet containing $100 \mathrm{~g}$ sucrose/kg; Fru, diet containing $100 \mathrm{~g}$ fructo-oligosaccharide/kg; Gal, diet containing $100 \mathrm{~g}$ galacto-oligosaccharide/kg.

a,b,c Mean values within a row not sharing a common superscript letter were significantly different, $P<0.05$.

* For details of diets and procedures, see Table 1 and pp. 469-471.

butyric acids were significantly $(P<0.05)$ higher in group Fru.

\section{Fatty acid composition in body fat (Table 7)}

Long-chain fatty acid composition in the body (without stomach and caecum and after bleeding) was affected especially by the addition of Fru, with higher values for linolenic and lower values for oleic, palmitic and stearic acids compared with group B. In group Gal, there were significant decreases in linoleic and oleic acids and an increase in myristic acid compared with group B. Groups BR and S showed similar fatty acid compositions. The total unsaturated fatty acids : total saturated fatty acids ratio was higher in group B than the other groups; there were no significant differences between any of the other groups.

\section{Discussion}

The weights of caecal tissue and caecal contents were greater, and the concentrations and amounts of organic acids in the caecal contents were much greater in rats fed with oligosaccharides than in rats fed on diets B and S. Similar effects of the addition of poly- and oligosaccharides such as pectin, sodium alginate, gum arabic, gum xanthan (Ikegami et al. 1990), fructo-oligosaccharide (Tokunaga et al. 1986), xylo-oligosaccharides (Imaizumi et al. 1991) and galactosylsucrose (Yoneyama et al. 1992; Hoshi et al. 1994) to the diet of rats on increases in the size, volume and pool size of organic acids of the large intestine have been reported previously. The change in retention times of liquid and particle digesta markers in reponse to addition of Fru and Gal is connected with an enlarged caecum which retains large amounts of digesta.

Tokunaga et al. (1986) showed that addition of fructooligosaccharide to the diet shortened digesta transit time, while in the present experiment there was no difference between basal groups and supplemented groups. Tokunaga et al. (1986) used a basal diet containing no fibre source; in contrast, cellulose $(100 \mathrm{~g} / \mathrm{kg})$ was included in the basal diet in the present experiment. This may explain the difference in the results. Moreover, a shorter transit time does not necessarily indicate a shorter retention time of digesta.

Longer mean retention times of digesta can support more complete decomposition and utilization of indigestible oligosaccharides by microbes in the large intestine. This might be expected to increase the amount of microbial $\mathrm{N}$ excreted in the faeces, which could explain the lower digestibility of $\mathrm{N}$ in rats fed with Fru and Gal.

It has been reported that addition of fructo-oligosaccharide to the diet increases the total absorption of $\mathrm{Ca}, \mathrm{Mg}$ and $\mathrm{P}$ in rats (Ohta et al. 1993) and stimulates absorption of Ca and $\mathrm{Mg}$ from the colon and rectum in rats (Ohta et al. 1995). Other indigestible carbohydrates such as resistant starch (Schulz et al. 1993) and inulin (Rémésy et al. 1993) have similar effects. These findings support the increased digestibility of crude ash by addition of Fru and Gal observed in the present study.

It is well established that fructo-oligosaccharides and galacto-oligosaccharides are mostly metabolized by intestinal micro-organisms and are utilized as an energy source. Only a small amount of ${ }^{14} \mathrm{C}$ was detected in faeces after oral administration of $\left[\mathrm{U}_{-}{ }^{14} \mathrm{C}\right]$ fructo-oligosaccharides in rats (Tokunaga et al. 1989) and in man (Hosoya et al. 1988). This means that the oligosaccharides are almost totally absorbed and utilized after microbial degradation.

Amounts and concentrations of organic acids in the caecum were much higher in rats fed with Fru and Gal than those in rats fed on diets B and S. This is considered to result from the fermentation of Fru and Gal. Organic acids, mainly SCFA are readily absorbed, and can be utilized as an energy source and as materials for biosynthetic reactions in the animal's tissues.

Calculations by Roberfroid et al. (1993) on the basis of the pathway of fermentation by microbes and the metabolism of organic acids absorbed by the host animal, yielded estimates of the metabolizable energy of oligofructose of between $4 \cdot 18$ and $7 \cdot 26 \mathrm{~kJ} / \mathrm{g}$. This is $25-40 \%$ of the chemical energy of oligofructose. The estimation using $\left[\mathrm{U}-{ }^{14} \mathrm{C}\right]$ fructo-oligosaccharides showed that the energy utilization of fructo-oligosaccharides was $6.3 \mathrm{~kJ} / \mathrm{g}$ in man (Hosoya et al. 1988).

The contributions to energy accumulation by Fru and Gal 
in the present experiment were much less than that by $\mathrm{S}$; the contribution by Fru was approximately $82 \%$ of that of $\mathrm{S}$, and that of Gal was approximately $41 \%$. These estimates are obtained by indirect means, but it is clear that the energy accumulation efficiency is different between Fru and Gal.

Concentrations of propionic acid and butyric acid were higher, but acetic acid concentration was lower, in group Fru than in group Gal. Several studies have shown that dietary propionate reduces serum cholesterol levels in rats (Chen et al. 1984; Illman et al. 1988) and pigs (Thacker et al. 1981), suggesting a possible effect of propionic acid on lipid metabolism. The chemical energy contents of butyric acid $(24.89 \mathrm{~kJ} / \mathrm{g})$ and propionic acid $(20.75 \mathrm{~kJ} / \mathrm{g})$ are much higher than that of acetic acid $(14.60 \mathrm{~kJ} / \mathrm{g}$ ) (Pond et al. 1995). Furthermore, production of ATP through metabolism of propionic and butyric acids is greater than that resulting from acetic acid. In group $\mathrm{Gal}$, the acetic acid: propionic acid ratio was large compared with that of group Fru. This probably explains the difference in energy accumulation efficiency between Fru and Gal.

Fru and Gal altered the fatty acid composition (unsaturated : saturated ratio) in the body. Some studies using ${ }^{14} \mathrm{C}$ labelled fructo-oligosaccharides and plant cell-wall material showed that significant amounts of poly- and oligosaccharides ingested were fermented to organic acids in the large intestine, then the organic acids were utilized as an energy source and as materials for synthesis of fatty acids and amino acids in the rat (Hosoya et al. 1988; Buchanan et al. $1994 a, b)$. In the liver the ${ }^{14} \mathrm{C}$, administered as $\left[\mathrm{U}^{14} \mathrm{C}\right]-$ labelled spinach cell walls, was predominantly associated with phospholipid (Buchanan et al. 1994a,b). This suggests that fermentation products of the cell walls were effectively utilized to synthesize fatty acids in the liver.

Acetic acid, of which the concentration in the caecum was higher in group Gal, is the primary substrate for cholesterol and triacylglycerol synthesis. Butyric acid, of which the concentration was higher in group Fru, is another source of acetyl-CoA as well as acetate. The synthesis of saturated fatty acids begins with acetyl-CoA. The supply of acetyl-CoA was probably much larger in groups Fru and Gal than the other groups. With free access to a starch-rich diet, NADH supply would not limit the utilization of acetate and butyrate. Under the feeding conditions in the present experiment, saturated fatty acids might easily be synthesized as a result of feeding Fru and Gal. This would result in a lower unsaturated : saturated fatty acids ratio. The difference in the relative levels of these SCFA in the caecum may therefore affect fatty acid composition in the body fat. This should be investigated by a tracer experiment using ${ }^{14} \mathrm{C}$-labelled SCFA.

In conclusion, Fru and Gal might increase the retention time of digesta in the rat. Contributions to energy accumulation of Fru and Gal are lower than those of starch or sucrose, and tend to be different, associated with differences in the composition of caecal organic acids and of fatty acids in body fat. Because the net energy value of each organic acid in the body and effects of organic acids, especially SCFA, on nutrient metabolism in the body may be different, the energetic contributions of indigestible oligosaccharides can be expected to vary depending on the extent to which they are fermented and on the relative amounts of each organic acid produced in the large intestine.

\section{Acknowledgements}

The authors are grateful to Professor S. Nakae and Professor S. Satoh, Notre Dame Seishin University for the use of the bomb calorimeter, to Meiji Seika Kaisha Ltd. (Tokyo) for supplying the fructo-oligosaccharide, to Yakult Honsha Co. Ltd. (Tokyo) for supplying the galacto-oligosaccharide, to Dr T. Yajima and Miss M. Kimura, Yakult Central Institute for Microbiological Research for the analysis of organic acids and to Professor I. D. Hume, School of Biological Sciences, University of Sydney, for his valuable suggestions and careful revision of the English expression in this paper.

\section{References}

Association of Official Analytical Chemists (1975) Official Methods of Analysis of the Association of Official Analytical Chemists, 12th ed. Washington, DC: Association of Official Analytical Chemists.

Brandt CS \& Thacker EJ (1958) A concept of rate of food passage through the gastrointestinal tract. Journal of Animal Science 17, 218-223.

Buchanan CA, Fry SC \& Eastwood MA (1994a) Metabolism and fate of dietary $\left(\mathrm{U}_{-}{ }^{14} \mathrm{C}\right)$-labelled spinach cell walls in the rat. Journal of the Science of Food and Agriculture 64, 135-140.

Buchanan CA, Fry SC \& Eastwood MA (1994b) The metabolism and fate of [methyl- ${ }^{14} \mathrm{C}$ ] and [uronate- $6-{ }^{14} \mathrm{C}$ ]pectin-labelled dietary plant cell wall in the rat. Journal of the Science of Food and Agriculture 66, 163-173.

Chen W-JL, Anderson JW \& Jennings D (1984) Propionate may mediate the hypocholesterolemic effects of certain soluble plant fibers in cholesterol fed rats. Proceedings of the Society for Experimental Biology and Medicine 175, 215-218.

Coombe JB \& Kay RNB (1965) Passage of digesta through the large intestines of the sheep: retention times in the small and large intestine. British Journal of Nutrition 19, 325-338.

Demigné C, Yacoub C, Rémésy C \& Fafournoux P (1986) Effects of absorption of large amounts of volatile fatty acids on rat liver metabolism. Journal of Nutrition 116, 77-86.

Duncan DB (1955) Multiple range and multiple F tests. Biometrics 11, 1-42.

Hagen P \& Robinson KW (1953) The production and absorption of volatile fatty acids in the intestine of the guinea-pig. Australian Journal of Experimental Biology and Medical Science 31, 99104

Henning SJ \& Hird FJR (1972) Ketogenesis from butyrate and acetate by the caecum and the colon of rabbits. Biochemical Journal 130, 785-790.

Hoshi S, Sakata T, Mikuni K, Hashimoto H \& Kimura S (1994) Galactosylsucrose and xylosylfructoside alter digestive tract size and concentrations of cecal organic acids in rats fed diets containing cholesterol and cholic acid. Journal of Nutrition 124, 52-60.

Hosoya N, Dhorranintra B \& Hidaka H (1988) Utilization of $\left[\mathrm{U}-{ }^{14} \mathrm{C}\right]$ fructooligosaccharides in man as energy resources. Journal of Clinical Biochemistry and Nutrition 5, 67-74.

Ikegami S, Tsuchihashi F, Harada H, Tsuchihashi N, Nishide E \& Innami S (1990) Effect of viscous indigestible polysaccharides on pancreatic-biliary secretion and digestive organs in rats. Journal of Nutrition 120, 353-360.

Illman RJ, Topping DL, McIntosh GH, Trimble RP, Storer GB, Taylor MN \& Cheng B-Q (1988) Hypocholesterolemic effects 
of dietary propionate: studies in whole animals and perfused rat liver. Annals of Nutrition and Metabolism 32, 97-107.

Imaizumi K, Nakatsu Y, Sato M, Sedarnawati Y \& Sugano M (1991) Effects of xylooligosaccharides on blood glucose, serum and liver lipids and cecum short-chain fatty acids in diabetic rats. Agricultural and Biological Chemistry 55, 199-205.

Kikuchi H \& Yajima T (1992) Correlation between water-holding capacity of different types of cellulose in vitro and gastrointestinal retention time in vivo of rats. Journal of the Science of Food and Agriculture 60, 139-146.

Matsumoto K, Kobayashi Y, Ueyama S, Watanabe T, Tanaka R, Kan T, Kuroda A \& Sumihara Y (1993). Galactooligosaccharides. In Japanese Technology Reviews, vol. 3, no. 2. Oligosaccharides: Production, Properties, and Applications, pp. 90-106 [T Nakakuki, editor]. Switzerland: Gordon and Breach Science Publishers.

Ohta A, Ohtsuki M, Baba S, Adachi T, Sakata T \& Sakaguchi E (1995) Calcium and magnesium absorption from the colon and rectum are increased in rats fed fructooligosaccharides. Journal of Nutrition 125, 2417-2424.

Ohta A, Osakabe N, Yamada K, Saito Y \& Hidaka H (1993) Effects of fructooligosaccharides on $\mathrm{Ca}, \mathrm{Mg}$ and $\mathrm{P}$ absorption in rats. Journal of the Japanese Society of Nutrition and Food Science 46, 123-129.

Pond WG, Church DC \& Pond KR (1995) Basic Animal Nutrition and Feeding, 4th ed., p. 151. New York, NY: John Wiley \& Sons.

Rémésy C, Levrat MA, Gamet I \& Demigné C (1993) Cecal fermentations in rats fed oligosaccharides (inulin) are modulated by dietary calcium level. American Journal of Physiology 264, G855-G862.

Roberfroid M, Gibson GR \& Delzenne N (1993) The biochemistry of oligofructose, a nondigestible fiber: an approach to calculate its caloric value. Nutrition Reviews 51, 137-146.

Roediger WEW (1980) Role of anaerobic bacteria in the metabolic welfare of the colonic mucosa in man. Gut 21, 793-798.

Schulz AGM, Amelsvoort JMM \& Beynen AC (1993) Dietary native resistant starch but not retrograded resistant starch raises magnesium and calcium absorption in rats. Journal of Nutrition 123, 1724-1731.

Schumann WC, Magnusson I, Chandramouli V, Rumaran K, Wahren J \& Randan BR (1991) Metabolism of $\left[2-{ }^{14}\right.$ C]acetate and its use in assessing hepatic Krebs cycle activity and gluconeogenesis. Journal of Biological Chemistry 266, 69856990.

Thacker PA, Salomons MO, Aherne FX, Milligan LP \& Bowland JP (1981) Influence of propionic acid on the cholesterol metabolism of pigs fed hypercholesterolemic diets. Canadian Journal of Animal Science 61, 969-975.

Tokunaga T, Oku T \& Hosoya N (1986) Influence of chronic intake of new sweetener fructooligosaccharide (Neosugar) on growth and gastrointestinal function of the rat. Journal of Nutritional Science and Vitaminology 32, 111-121.

Tokunaga T, Oku T \& Hosoya N (1989) Utilization and excretion of a new sweetener, fructooligosaccharide (neosugar), in rats. Journal of Nutrition 119, 553-559.

Udén P, Colucci PE \& Van Soest PJ (1980) Investigation of chromium, cerium and cobalt as markers in digesta rate of passage studies. Journal of the Science of Food and Agriculture 31, 625-632.

Van Soest PJ (1963) The use of detergents in the analysis of fibrous feeds. II. A rapid method for the determination of fiber and lignin. Journal of the Association of Official Analytical Chemists 46, 829-835.

Van Soest PJ \& Wine RH (1967) Use of detergents in the analysis of fibrous feeds. IV. Determination of plant cell-wall constituents. Journal of the Association of Official Analytical Chemists 50, 50-55.

Williams CH, David DJ \& Iismaa O (1962) The determination of chromic oxide in faeces samples by atomic absorption spectrophotometry. Journal of Agricultural Science, Cambridge 59, 381-385.

Yoneyama M, Mandai T, Aga H, Fujii K, Sakai S, Shintani T, Mou K \& Katayama (Sugawa) Y (1992) Effect of lactosucrose feeding on cecal $\mathrm{pH}$, short-chain fatty acid concentration and microflora in rats. Nippon Eiyo Shokuryou Gakkaishi 45, 109-115. 